\title{
Społeczna odpowiedzialność jako strategia zarządzania uniwersytetem
} \author{
\begin{tabular}{l|l} 
Wioleta Gaweł & $\begin{array}{l}\text { Wydział Ekonomii i Stosunków Międzynarodowych, } \\
\text { Uniwersytet Ekonomiczny w Krakowie }\end{array}$
\end{tabular}
}

Słowa kluczowe: społeczna odpowiedzialność, zarządzanie, uczelnie

Keywords: social responsibility, management, universities

\section{Streszczenie}

Dotychczasowe próby usystematyzowania zasad odpowiedzialności społecznej uczelni w polskich realiach opierały się na systemach korporacyjnych. Jednak implementacja zasad korporacyjnych w przestrzeni uniwersytetu jest nieuzasadniona z punktu widzenia odmiennych celów, jakie ma uczelnia, wobec tych, do których dążą podmioty gospodarcze. Spoglądając na sektor biznesu, gdzie koncepcja odpowiedzialności społecznej o wiele prężniej się rozwija, okazuje się, że działania prowadzone w oparciu o strategię danej organizacji są najbardziej efektywne. Strategiczne zasady odpowiedzialności społecznej w przypadku podmiotów biznesowych powstały w wyniku przypisania ich do konkretnych zadań, jakich podejmuje się przedsiębiorstwo. Taka sama strategia wyznaczania zasad odpowiedzialności powinna być przyjęta przez uczelnie wyższe. Celem opracowania jest próba wyznaczenia norm do zarządzania społeczną odpowiedzialnością uczelni.

\section{Social responsibility as management strategy of the university Summary}

Previous attempts to systematize the principles of social responsibility of Polish universities were based on corporate systems. However, the implementation of corporate rules in the university space is unjustified from the point of view of the different goals that the university has to those towards which the business is pursuing. Looking at the business sector, where the concept of social responsibility is much more evolving, it turns out that strategic implementation is based on the strategies of the organization. Strategic principles of corporate social responsibility in the case of business entities have arisen as a result of assigning them to specific tasks undertaken by the enterprise. The same strategy for setting the rules of responsibility should be adopted by universities. The aim of this study is to try to set standards for managing the university's social responsibility. 


\section{Wstęp}

Podejście do społecznej odpowiedzialności w kontekście zarządzania uczelnią wymaga głębszej refleksji nad zarządzaniem takim typem instytucji. Przede wszystkim należy przyjrzeć się modelom zarządzania występującym w przypadku uniwersytetów. Mimo że nie są one związane z zarządzaniem odpowiedzialnością w bezpośredni sposób, to warunkują strukturę zarządzania i fundamentalne zasady, na których będzie się opierać strategia społecznej odpowiedzialności.

Próba zarządzania uczelnią zgodnie ze strategią społecznej odpowiedzialności biznesu wymaga starannego przygotowania całej organizacji. Rzetelne podejście do tego procesu wyznacza jednak kierunek działań w perspektywie długookresowej, a nie polega tylko na chwilowych rozwiązaniach. Po podjęciu decyzji o zarządzaniu w sposób odpowiedzialny organizacja powinna dobrać narzędzia, które usystematyzują cały proces. Dotychczasowe próby wdrażania społecznej odpowiedzialności w kontekście uniwersytetu oparte były na kopiowaniu rozwiązań funkcjonujących w sektorze biznesowym. Właściwsze natomiast jest odwołanie się do treści norm związanych z odpowiedzialnością społeczną, co zostanie wykazane w artykule.

\section{Uwarunkowania zarządzania uczelnią}

Zarządzanie tak skomplikowaną instytucją, jaką jest uczelnia, wymaga wielowymiarowego podejścia. W literaturze pojawia się pojęcie ładu akademickiego, mające systematyzować funkcjonowanie uniwersytetu. Według J. Thieme’a ład organizacyjny uwzględnia procesy oraz rozwiązania organizacyjne, które pozwalają na sprawne funkcjonowanie procesów edukacyjnych, obejmujących szkolnictwo wyższe. Istotą definicji ładu akademickiego jest również wyodrębnienie makroładu (zewnętrzny ład organizacyjny) i mikroładu (wewnętrzny ład organizacyjny) (Thieme 2009: 61). Na tak ukształtowany obraz podejścia do zarządzania uczelnią nakładają się jeszcze mechanizmy związane z kontrolą i koordynacją. Według J. Frieda stanowią je regulacje zewnętrzne, ukierunkowania zewnętrzne, samorządność menedżerska oraz samorządność akademicka. Regulacje zewnętrzne związane są z uprawnieniami danego państwa do ustalania zasad, na których będzie funkcjonować uczelnia. Uwarunkowania zewnętrzne dotyczą interesariuszy zewnętrznych, czyli ich uprawnień jako członków chociażby w radach uczelnianych czy innych powołanych organach. Samorządność menedżerska odnosi się do kadry wyższego szczebla, której zadaniem jest wytyczenie kierunków rozwoju i funkcjonowania uczelni. Samorządność akademicka jest ponadto związana z całą społecznością, gdzie wspólnie podejmowane są decyzje (Kuźmicz 2015: 20-21).

W Polsce kierunki strategiczne rozwoju szkolnictwa wyznaczane są przez organizatora nauki, a więc przez organ centralny, którym jest Ministerstwo Nauki i Szkolnictwa Wyższego. Wsparcie dla ministerstwa stanowi organ kolegialny, którym jest Rada Główna 
Szkolnictwa Wyższego. Znaczącą rolę w procesie zarządzania uczelniami odgrywają również jednostki akredytujące. Zaliczamy do nich Polską Komisję Akredytacyjną (PKA), Uniwersytecką Komisję Akredytacyjną (UKA), Komisję Akredytacyjną Uczelni Technicznych (KAUT), jak również niezależne instytucje międzynarodowe. Znaczenie również mają konferencje: rektorów, kwestorów czy kanclerzy. Zajmują się opiniowaniem aktów prawnych i przedstawiają swoje stanowisko w istotnych kwestiach dla szkolnictwa wyższego (Kuźmicz 2015: 20-21).

\section{Modele zarządzania uczelniami w Polsce}

Zgodnie z raportem końcowym sporządzonym przez Centrum Badań nad Szkolnictwem Wyższym: Modele zarządzania uczelniami w Polsce wyróżnić możemy cztery modele funkcjonujące w Polsce: elekcyjno-unikameralny, elekcyjno-bikameralny, konkursowo-unikameralny, konkursowo-bikameralny. Każdy z modeli zakłada cztery elementy, w obrębie których różni się składowymi: planowanie, organizowanie, motywowanie/przewodzenie oraz kontrola. Zgodnie z zasadą autonomiczności uczelni jednostka sama podejmuje decyzję o wyborze konkretnego modelu. Decyzja ta zapada w wyniku decyzji Senatu poprzez przyjęcie lub zmianę statutu. Przed takim wyborem stoją wszystkie typy szkół wyższych w Polsce. Waga tej decyzji jest zatem bardzo duża, zwłaszcza w aspekcie kształtu, w jakim będzie funkcjonować uczelnia, a także jak będzie wyglądało w niej zarządzanie i jak będzie kierowana. Wybór modelu nie jest jednak ostateczny i może być on zmieniany w toku funkcjonowania uczelni (Vall i in. 2011: 57-69).

Polskie uczelnie najczęściej stosują model elekcyjno-unikameralny. Dominacja tego modelu jest ponadto widoczna wśród uczelni ze stosunkowo długą historią i tradycjami akademickimi. W tym modelu uczelnia posiada tylko senat, który stanowi organ kolegialny o charakterze międzyuczelnianym, a rektor pochodzi z wyboru. Jest to model samorządności akademickiej. Kolejny z modeli, elekcyjno-bikameralny, obok senatu posiada konwent, natomiast rektor jest wybierany. Jest to również model samorządności akademickiej. W praktyce model ten nie jest często stosowany przez uczelnie, a niektóre nawet nie dopuszczają możliwości, by w ramach takiego modelu funkcjonować. Forma bikameralności jest wymagana przez prawo w odniesieniu do publicznych uczelni zawodowych. Kolejny model, konkursowo-unikameralny, jest stosowany przede wszystkim w uczelniach niepublicznych. W modelu tym mamy do czynienia z samorządnością menedżerską oraz senatem przy rektorze, wyłonionym w ramach konkursu. Ostatni z modeli, konkursowo-bikameralny, jest modelem samorządności menedżerskiej. Rektor również jest wybierany w ramach konkursu, a obok senatu funkcjonuje konwent (Vall i in. 2011: 57-69). 


\section{Zarządzanie poprzez społeczną odpowiedzialność}

Rosnąca świadomość u przedsiębiorców w kontekście odpowiedzialności społecznej powoduje, że staje się ona częścią strategii zarządzania przedsiębiorstwa. Wśród przesłanek wskazujących na konieczność budowania strategii przedsiębiorstwa w zarysowanym kierunku wymieniane jest przede wszystkim zmieniające się otoczenie społeczno-gospodarcze. Mamy do czynienia z procesem kształtowania się społeczeństwa obywatelskiego i coraz bardziej świadomych konsumentów, którzy podejmując decyzje zakupowe, biorą pod uwagę o wiele więcej czynników aniżeli tylko kryterium ceny w odniesieniu do jakości. Znaczenie odgrywa także miejsce produkcji, skład, jak również cała polityka firmy. Wśród przesłanek są także stricte biznesowe argumenty. Strategia społecznej odpowiedzialności buduje bowiem przewagę konkurencyjną i pozwala na wzrost znaczenia zasobów niematerialnych firmy. Zmienia się również podejście inwestorów, dla których wyniki finansowe to nie wszystko. W ten sposób organizacje bardziej lub mniej świadomie zaczynają dążyć do zrównoważonego rozwoju, który odrzuca pogoń za zyskiem z pominięciem całego otoczenia, włączając do wymiaru ekonomicznego również społeczeństwo i środowisko (Zapłata, Kaźmierczak 2011: 160-161).

W przypadku uczelni wyższych koncepcja zarządzania odpowiedzialnością społeczną jest o wiele mniej popularna i usystematyzowana. Jednakże przesłanki przemawiające za odpowiedzialnością społeczną przedsiębiorstw skłaniają również do przyjrzenia się tej koncepcji z punktu widzenia implementacji takiego sposobu funkcjonowania w przestrzeni uczelni wyższej. Z jednej strony rosnąca świadomość społeczeństwa powoduje, że uczelnie powinny strategicznie podchodzić do kwestii związanych ze społeczną odpowiedzialnością, a z drugiej strony - edukacja wpływa na postawy i podejmowane decyzje w dorosłym życiu. Oznacza to, że budowanie odpowiedzialnego biznesu, a dalej - odpowiedzialnej gospodarki, jest w pewnym zakresie uwarunkowane charakterem edukacji.

Zarządzanie zgodnie z zasadami odpowiedzialności społecznej wymaga od organizacji, bez względu na jaj charakter, podjęcia odpowiednich kroków, które umożliwią strategiczne podejście do tego zagadnienia. W pierwszym rzędzie organizacja powinna określić swoją misję i wartości, zgodnie z którymi będzie funkcjonować i które będą priorytetem bez względu na zmieniające się warunki zewnętrzne. Następnie na tej podstawie może dopiero stworzyć i wprowadzić w życie politykę społeczną. Kolejno organizacja powinna zidentyfikować interesariuszy oraz określić ich wpływ, aby w następnym kroku stworzyć programy współpracy z grupami otoczenia. Ostatnim krokiem jest natomiast wprowadzenie idei zarządzania do całej firmy i jej wdrożenie na każdym szczeblu, tak aby cała strategia była spójna i znana na każdym szczeblu zarządzania (Witek-Crabb 2001: 152-159). 


\section{Implementacja standardów społecznej odpowiedzialności}

Podjęcie decyzji o zarządzaniu w myśl społecznej odpowiedzialności to dopiero początek drogi do budowy organizacji odpowiedzialnej społecznej. Podobnie określenie misji i fundamentalnych wartości, a następnie interesariuszy, wciąż nie wskazuje bardziej szczegółowych zasad zarządzania. Jest to zadanie, które wypełniają standardy. Do najpopularniejszych należą standard SA 8000, AA 1000, a także wytyczne odpowiedzialności społecznej według ISO 26000.

Norma SA 8000 została opublikowana w 1997 r. przez Council on Economics Priorities Accreditation Agency. Obecnie funkcjonuje już trzecia wersja normy z 2008 r. SA 8000 opiera się na wartościach wynikających z konwencji międzynarodowych, opracowanych przez ONZ. Norma podzielona jest na trzy części: wstęp wraz z objaśnieniami stosowanych pojęć, druga część określa warunki wstępne, a więc wymagania twarde, trzecia część natomiast podaje warunki budowy systemu, które stanowią wymagania miękkie (Klaniewski 2008). Dwa lata po pierwszej publikacji normy ukazał się poradnik pomagający organizacjom wdrożyć normę, a audytorom zweryfikować poprawność przeprowadzonego procesu: Guidance Document for Social Accountability SA 8000. Oprócz wymagań stawianych przez normę przedstawia ona również przydatne narzędzia oraz przykłady (Kaźmierczak 2010: 358).

Przystępując do wdrażania normy SA 8000, organizacja w pierwszym rzędzie powinna spełnić wymaganie twarde, wśród których wyróżniamy:

1) praca dzieci,

2) praca przymusowa,

3) bezpieczeństwo i higiena pracy,

4) prawo do zrzeszania się i rokowań układu zbiorowego,

5) dyskryminacja,

6) praktyki dyskryminujące,

7) godziny pracy,

8) wynagrodzenie,

9) systemy zarządzania (Pracodawcy RP 2016: 15-19).

Do realizacji punktu dziewiątego organizacja może przystąpić dopiero po wypełnieniu wszystkich wcześniejszych ośmiu. Na ten etap związany z budową strategii zarządzania w myśl społecznej odpowiedzialności składa się szesnaście elementów, które są tzw. wymaganiami miękkimi. Pierwszy z nich to polityka społecznej odpowiedzialności. Ustanawia ją kierownictwo organizacji, podobnie jak politykę jakości. Zakłada się, że powinna być znana przez wszystkich interesariuszy, a przynajmniej dla nich dostępna.W tym aspekcie dużą rolę odgrywa kierownictwo, które powinno zapewnić, że polityka ta będzie spójna z celem organizacji, formułowana zgodnie z prawem i w sposób ciągły. To oznacza, że powinna być ulepszana zgodnie ze zmieniającą się rzeczywistością oraz powinna być dostępna do publicznej wiadomości. Kolejny element to powołanie pełnomocnika ds. systemu zarządzania społeczną odpowiedzialnością, którego 
zadaniem jest zapewnienie, że wymagania normy zostały wdrożone. Druga funkcja konieczna do wypełnienia to zapewnienie reprezentacji pracowników poprzez powołanie ich przedstawiciela ds. SA 8000. Trzecim elementem systemu zarządzania jest przegląd zarządzania. W ramach tego elementu istotne jest, aby kierownictwo przeprowadzało zaprojektowany system zarządzania społeczną odpowiedzialnością, tak aby można było mówić o jego stałej adekwatności, przydatności oraz skuteczności. Następnym elementem jest planowanie i wdrożenie. W tym zakresie zadaniem organizacji jest weryfikacja, na ile wymagania są zrozumiałe i czy zostaną wdrożone na wszystkich poziomach organizacji. Konieczne jest zatem jasne określenie ról i odpowiedzialności oraz stały monitoring. Szóstym elementem jest odniesienie do przewodnika SA 8000. Jest to szczególnie istotne na etapie interpretacji poszczególnych wymagań. Kolejnym elementem strategii zarządzania jest nadzorowanie dostawców i poddostawców. Ten element zakłada odpowiedzialność większą aniżeli tylko własna. Zgodnie z tym punktem organizacja będzie kontrolować postępowanie swoich interesariuszy, na ile jest zgodne z zasadami społecznej odpowiedzialności. Kolejny element jest związany z poprzedzającym; dotyczy doboru podwykonawców oraz poddostawców. W tym celu konieczne jest opracowanie procedur doboru. Kolejny element, współpraca z dostawcami, również nawiązuje do dwóch poprzednich i stanowi zapewnienie o współpracy. Dziesiąty element wymagań miękkich dotyczy prac chałupniczych. Zadaniem organizacji jest nadzorowanie prac wykonywanych w takim charakterze. Następny element dotyczy już innego obszaru związanego z niedociągnięciami. Organizacja powinna stwarzać warunki do składania skarg i zażaleń, dotyczących niezgodności z wymaganiami normy. Następnym elementem są działania korygujące i zapobiegawcze. Duże znaczenie przykłada się do identyfikowania przyczyn wszelkich niedogodności oraz inicjowania działań korygujących i zapobiegawczych. W trzynastym elemencie mowa o komunikacji zewnętrznej i zaangażowaniu interesariuszy. W tym celu konieczne jest stworzenie procedury, która pozwoli na stałą komunikację z interesariuszami i informowanie o ich postępowaniu zgodnie z normami. Następny element jest z tym aspektem nieodzownie związany - nakazuje bowiem dialog ze wszystkimi interesariuszami. Przedostatni element związany jest z umożliwieniem audytorowi przeprowadzenia kontroli, nawet w sytuacji, gdy była ona niezapowiedziana. Ostatni element to zapisy dotyczące przechowywania dokumentacji potwierdzającej postępowanie zgodnie z wymaganiami normy (Zapłata, Kaźmierczak 2011: 160-161).

Podejście strategiczne do społecznej odpowiedzialności wyznacza również standard AA 1000. Został on opracowany przez Institute of Social and Ethical AccountAbility w 1999 r. Składa się z trzech elementów:

- AA 1000 AS (Assurance Standard);

- AA 1000 SES (Stakeholders Engagement Standard);

- AA 1000 APS (AccountAbility Principles Standard). 
Spełnia on trzy zasadnicze zadania. Przede wszystkim promuje odpowiedzialność społeczną w ujęciu zarządzania organizacją. Prowadzi do wzmocnienia zasad obejmujących odpowiedzialność społeczną, a także poprawia jakość audytu etycznego i wzmacnia komunikację z interesariuszami. Zaletą standardu AA 1000 jest również to, że przyczynia się do poprawy aspektów etycznych, ekologicznych i ekonomicznych w organizacji (Ocieczek, Gajdzik 2010: 86).

Norma AA 1000 służy do przeprowadzania audytu etycznego, który następnie może być wykorzystywany w analizie strategicznej. Sam audyt etyczny często używany jest z pobudek związanych z zarządzaniem personelem, takich jak: obniżenie poziomu stresu wśród pracowników, zmniejszenie fluktuacji czy podniesienie efektywności. Jest używany również, aby poprawić relacje z klientami, a przede wszystkim, aby określić standardy moralne funkcjonujące $w$ organizacji. Proces przeprowadzania audytu etycznego w organizacji przedstawia się następująco:

- wola przeprowadzenia audytu,

- identyfikacja interesariuszy,

- sformułowanie misji i określenie wartości, na których opiera się funkcjonowanie organizacji,

- podjęcie decyzji o zakresie, metodach oraz celach strategicznych,

- przyjęcie wskaźników i sposobów ich weryfikacji,

- zebranie informacji od interesariuszy,

- analiza zebranych informacji i opracowanie metod doskonalenia,

- przygotowanie raportu,

- audyt przeprowadzonego raportu,

- upublicznienie raportu i zachęcenie do przekazywania informacji zwrotnych,

- opracowanie procedur wdrożenia do analizy strategicznej uzyskanych wyników oraz wytycznych (Rok 2001: 174).

Istotą normy AA 1000 jest to, że nie podlega ona certyfikacji. Stanowi jedynie narzędzie wspomagające zarządzanie społeczną odpowiedzialnością. Warunkiem sukcesu implementacji normy jest podejście do niej w sposób systemowy, skrupulatne wdrażanie wszystkich zasad, a także ich bieżące monitorowanie (Żemigała 2007: 12).

Znaną i jedną z bardziej popularnych norm służących do strategicznego wdrażania koncepcji społecznej odpowiedzialności biznesu jest ISO 26000. W przeciwieństwie do normy SA 8000 i AA 1000 jest ona bardziej kompleksowa. Wcześniej zaprezentowane normy podejmują się wybranych aspektów odpowiedzialności społecznej, stąd też twórcy ISO 26000 podkreślają, że została stworzona w oparciu o dotychczas funkcjonujące normy, a także o zasady Global Compact oraz Międzynarodowej Organizacji Pracy. Konstruowanie normy przez Organizację Normalizacyjną ISO rozpoczęło się w 2004 r., a prace zostały sfinalizowane dopiero w 2010 r. Zostały wtedy opublikowane wytyczne odpowiedzialności społecznej - Guidance on Social Responsibility. Norma ma charakter dobrowolny i, jak zapewniają jej twórcy, może być stosowana przez każdy rodzaj organizacji bez względu na charakter własności czy poziom 
rozwoju kraju, w którym funkcjonuje. Prace przygotowawcze do tworzenia normy rozpoczęły się jednak o wiele wcześniej. Już w 2001 r. został powołany Komitet ds. Polityki Konsumenckiej, którego zadaniem była weryfikacja, na ile możliwe jest opracowanie normy odpowiedzialności społecznej. Prace komitetu potwierdziły zasadność rozpoczęcia prac nad stworzeniem poradnika odpowiedzialności społecznej, dlatego została powołana Grupa Robocza ds. Społecznej Odpowiedzialności. Skład grupy był bardzo zróżnicowany, należeli do niej reprezentanci rządów, przedsiębiorstw, pracowników, organizacji pozarządowych, a także sektora usług i świata nauki. Miało to zapewnić uwzględnienie interesu wszystkich interesariuszy (Zapłata, Kazimierczak 2011: 160-161).

Zgodnie z normą ISO 26000 społeczna odpowiedzialność stanowi odpowiedzialność organizacji za wpływ jej decyzji i działań na społeczeństwo i środowisko, zapewnianą poprzez przejrzyste i etyczne postępowanie, które:

- przyczynia się do zrównoważonego rozwoju, w tym dobrobytu i zdrowia społeczeństwa;

- uwzględnia oczekiwania interesariuszy;

- jest zgodne z obowiązującym prawem i spójne z międzynarodowymi normami postępowania oraz

- jest zintegrowane $z$ działaniami organizacji i praktykowane w jej relacjach (PN-ISO 26000 2012: 15-16).

Kompleksowość normy ISO 26000 podkreśla sama jej struktura. Została podzielona na siedem rozdziałów, które są poprzedzone wprowadzeniem. Pierwszy rozdział Zakres normy zawiera przeznaczenie normy, jej ograniczenia, a także, jak sama nazwa wskazuje, określa zakres normy. Drugi rozdział poświęcony jest terminom i definicjom, co ma ogromne znaczenie dla koncepcji odpowiedzialności społecznej, która w bardzo różny sposób jest definiowana w literaturze. Norma przyczyniła się zatem do systematyzacji używanej terminologii. Trzeci rozdział zawiera krótki rys koncepcji społecznej odpowiedzialności, aktualne podejście do koncepcji, a przede wszystkim marginalizowany temat związany z odpowiedzialnością w sektorze małych i średnich przedsiębiorstw. Rozdział czwarty zatytułowany: Zasady społecznejodpowiedzialności to ogólne wytyczne dla koncepcji odnoszące się również do każdego z jej obszarów. Przyjmowanymi zasadami społecznej odpowiedzialności są: rozliczalność z wpływu wywieranego na otoczenie, przejrzystość decyzji i podejmowanych działań przez organizacje, postępowanie etyczne, uwzględnianie interesów interesariuszy, poszanowanie prawa i międzynarodowych norm postępowania oraz poszanowanie praw człowieka. Rozdział piąty poświęcony jest kwestii identyfikacji odpowiedzialności organizacji. Podejmuje takie kwestie, jak identyfikacja obszarów wpływu oraz angażowanie interesariuszy. W szóstym rozdziale zawarte są obszary społecznej odpowiedzialności, których identyfikacja i precyzyjne dookreślenie stanowi ogromne znaczenie w systematyzacji koncepcji społecznej odpowiedzialności. W normie zostało wyodrębnionych siedem ogólnych obszarów, które można zidentyfikować w ramach każdej organizacji: 
- ład organizacyjny,

- prawa człowieka,

- praktyki z zakresu pracy,

- środowisko,

- uczciwe praktyki operacyjne,

- zagadnienia konsumenckie,

- zaangażowanie społeczne i rozwój społeczności lokalnej.

Siódmy rozdział natomiast to wytyczne dotyczące praktycznej realizacji koncepcji odpowiedzialności społecznej. Podejmowana jest tu kwestia integrowania dobrych praktyk CSR z działalnością organizacji, ich ewaluacji i doskonalenia. Ponadto jeden z załączników do normy zawiera wiele przykładów zaangażowania oraz narzędzia na rzecz odpowiedzialności społecznej (PN-ISO 26000 2012: 30-31).

\section{Zakończenie}

Dokładniejsze przyjrzenie się normom z zakresu społecznej odpowiedzialności biznesu pozwala stwierdzić, że w żaden sposób nie zostały one nakierowane wyłącznie na podmioty biznesowe. Wstęp do normy ISO 26000 wręcz wprost określa, że jest to norma przystosowana do każdego typu organizacji. Częste występowanie tych norm w sektorze biznesowym spowodowane jest jedynie popularnością koncepcji społecznej odpowiedzialności w tym obszarze. Wdrożenie norm w obszarze uczelni będzie zadaniem trudnym z racji braku wcześniejszych prób uczynienia tego. Jednak efekty tych działań z punktu widzenia społecznego będą istotne.

Wdrażanie społecznej odpowiedzialności w obszar uczelni wymaga nowego podejścia, które będzie oparte na specyfice i modelu zarządzania sektora szkolnictwa wyższego. Niemożliwe jest dokładne skopiowanie strategii zarządzania społeczną odpowiedzialnością z przedsiębiorstw, które stawiają sobie inne cele i których funkcjonowanie oparte jest na innych zasadach. Zastanawiając się nad społeczną odpowiedzialnością biznesu, stwierdzić należy, że strategiczne podejście do koncepcji wynika z implementacji zasad odpowiedzialności do strategii zarządzania przedsiębiorstwem. Zatem próby wdrażania odpowiedzialności w przestrzeni uczelni powinny mieć miejsce w strategii zarządzania. Tylko takie podejście pozwala na podjęcie działań adekwatnych do charakteru instytucji oraz na wdrażanie koncepcji w strukturze całej organizacji. Uczelnia powinna zatem posiadać zasady odpowiedzialności społecznej, które w sposób naturalny przekładałyby się na strategię. 


\section{Bibliografia}

Kaźmierczak M., 2010, Działania normalizacyjne w zarzq̨dzaniu społecznq odpowiedzialnością [w:] J. Łańcucki, Znormalizowane systemy zarządzania, Poznań:Wydawnictwo Uniwersytetu Ekonomicznego w Poznaniu.

Kuźmicz K.A., 2015, Benchmarking procesowy jako instrument doskonalenia zarzq̨dzania uczelniq, Warszawa: Wolters Kluwers.

Ocieczek W., Gajdzik B., 2010, Społeczna odpowiedzialność przedsiębiorstw produkcyjnych, Gliwice: Wydawnictwo Politechniki Śląskiej.

Polskie wydanie normy SA 8000 wraz z przewodnikiem i komentarzami, 2013, Warszawa: Pracodawcy RP.

Rok B., 2001, Audyt etyczny według reguł AA 1000 jako narzędzie edukacji menadżerskiej [w:] W. Gasparski, A. Lewicka-Strzałeck (red.), Etyka biznesu jako przedmiot nauczania, Warszawa: Wydawnictwo Wyższej Szkoły Przedsiębiorczości Zarządzania im. L. Koźmińskiego w Warszawie.

Thieme J.K., 2009, Szkolnictwo wyższe. Wyzwania XXI. Polska, Europa, USA, Warszawa: Difin.

Vall M. i in., 2011, Modele zarządzania uczelniami w Polsce. Raport końcowy, Kraków: Uniwersytet Jagielloński, Centrum Badań nad Szkolnictwem Wyższym.

Witek-Crabb A., 2001, Zrównoważony rozwój przedsiębiorstw w praktyce gospodarczej [w:] R. Pajda (red.), Wybrane zagadnienia współczesnej ekonomii, Kraków: Akademia Górniczo-Hutnicza w Krakowie.

Wytyczne dotyczące społecznej odpowiedzialności, 2012, PN-ISO 26000, Warszawa.

Zapłata S., Kaźmierczak M., 2011, Ryzyko ciagłości biznesu, odpowiedzialność społeczna. Nowoczesne koncepcje zarządzania, Warszawa: Wolters Kluwers.

Żemigała M., 2007, Standard AA 1000 nowoczesnym narzędziem zarządzania z zakresu CSR, „Problemy Jakości", nr 11. 